\title{
8. Leszek M. Krusiński, Znaczenie wyrazów "fides" 1 "fidelis" w "De Trinitate" św. Augustyna, Lublin 1985, maszynopis, s. 150 .
}

Praca magisterska powstała w Sekcji Filologii Klasycznej KUL pod kierownictwem ks. doc. dra hab. H. Wójtowicza, orientowana jest raczej teologicznie, a allalizy językowe są tłem do takich rozwazań. Rozprawa składa się z następujących części: Spis treśc1/s. 1-5/, przedstawiający szczegółowo problematykę pracy, Wstęp /s. 6-12/, Rozdz. I: Znaczenia wyrazów "fides" i "fidelis" występujących "De Trinitate" św. Augustyna jako cytaty z Pisma św. lub aluzje do miejsc z Biblii/s. 32-52/, Rozdz. II: Znaczenie wyrazu "fides" /s. 53-88/, Rozdz. III: Znaczenie wyrazu "Pidelis"/s. 89-102/, Zakończenie /s. 103-106/, Przypisy /s. 107-114/, Wykaz skrótów/s. 115/, B1bl10grafia /s. 116-121, Summary /s . 122-123/, Zusammenfassung /s • 124125/ oraz Indeksy Nr 1-7/s. 1-25/z kompletnym wykazem: 1/ 1lości miejsc, w których występuje wyraz "fides" i "fidelis"; 2/ miejsc w których występuje wyraz "fides" i "fidelis" w tekście odautorskim i w cytatach lub aluzjach biblijnych oraz w dwukrotnie przytoczonym tekście z wyrazem "fides" z platońskiego "Timajosa"; 3 i $4 /$ połączeń czasownikowych i rzeczownikowych wyrazu "fides"; $5 /$ określeń charakteryzujących wyraz "fides", 6/ miejsc, w których występuje czasownik "credere" $i$ jego pochodne zarówno w tekście odautorskim, jak i w cytatach z Pisma św.; 7/ wybór synonimicznych wyrazów mających związek z wyrazami "fides" 1 "pidelis".

We wstępie autor omawia przedmiot, cel, aspekt 1 metodę pracy, podaje sposób traktowania wyrazów należących do tematu wiary, uwzglę. dnia obecny stan badań dotyczzcy omawianego zagadnienia oraz prezentuje kompozycję pracy. "Wprowadzenie" zaś obejnuje historię wyrazu "fides", określa jego etymologie w śwletle nauk1 współczesnej i źródeł antycznych, przytacza starożytne definicje "fides", przedstawia najczęściej spotykane znaczenia tego słowa oraz charakteryzuje kulty bóstw wierności, zwłaszcza bogini Bona fides, z uwzględnieniem jej wyobrażeń, atrybutów, symboli i epitetów.

Rozdziak I dzieli się na trzy paragrafy, które podają znaczenia wyrazów "fides" $i$ "fidelis", występujących w tekstach cytowanych przez Augustyna w "De Trinitate": najpierw przedstawia znaczenie wyrazów "fides" i "fidelis" funkcjonujących jako zapożyczenia z Biblii, 
a następnie znaczenie słowa "fides", które Augustyn przytacza z platońskiego Timajosa. Okazuje się, że treść wyrazu "fides" łączy się z pojęciem wiary chrześcijańskiej/fides christiana/ i z semantycznego punktu widzenia ma znaczenie jednorudne, określane jako "wiara w coś", "ufność do czegos", "wierzenie" i "ortodoksyjna wiara chrześcijańska". Z teologicznego punktu widzenia słowo "fides", w znaczeniu wiary chrześcijańskiej, funkcjonuje w omawianych przypadkach jako określenie źródeł wiary, chrztu i skutków wiary oraz dotyczy relacji między wiarą a uczynkami i wiarą a cudem. Wyraz "fidelis" zaś występuje jako rzeczownik w liczbie mnogiej i znaczy: "wierni", "chrzescijanie", "nawrócent"• Jako przymiotnik wystepuje on tylko raz i znaczy: "wierny", "pewny", "niezawodny", "godny zaufania", "taki, na któryin można polegać" i jest epitetem charakteryzującym Boga w sposób stały/fidelis Deus/.

W rozdziale II omówione zostały znaczenia badanego wyrazu w tekstach odaugustyńskich. Najpierw przedstawiono pozareligijne użycie wyrazu "fides", który ma tutaj następujące znaczenia: "wierność", "pewne świadectwo", "wiarygodność", "zaufanie", "przeświadczenie, przekonanie, że coś jest prawdą". Następnie ukazano religijne użycie badanego wyrazu, którego znaczenie $z$ punktu widzenia semantyki jest w tym przypadku jednorodne. "Fides" to "wiara", "wierzenie", które są rozumiane jako intelektualna akceptacja chrześcijańskich prawd objawionych, przejawiająca się w określonym światopoglądzie i postawie moralnej. Funkcjonalnie termin "fides" oznacza: źródła wiary chrześcijańskiej/Pismo św., naukę innych osób, własne rozmyślania, łaskę Bożą/; przedmiot wiary/Chrystus i jego dzieła, Boskie obietnice 1 oczekiwanie rzeczy eschatologicznycis/; skutki wiary /zbawienie, szczęście wieczne, pokorę, doskonalenie się, pobożność, wolność od strachu przed cierpieniem i śmiercią, połaczenie się z Bogiem/; relację między wiarą a cuden i między wiarą a wiedzą. Uwzględniono tu równiez biblijne przykłady wiary, jej metafory 1 epitety oraz omówiono "fides" rozumianą jako akt wiary/fides qua creditur/, a także problem istnienia wiary / pides/w doczesności i wieczności.

Przedmiotem III rozdziału jest badanie pola semantycznego wyrazu "fidelis" i próba określenia desygnatów tego słowa w tekstach pochodzących od św. Augustyna. Za podstawę do wyodrębnienia różnych znaczeń badanego wyrazu przyjęto jego użycie przymiotnikowe 
i rzeczownikowe. "Fidelis", jako przymiotnik znaczy "wierny", odnosi się do abstraktu, określa duszę człowieka i jej pobożność. "Fidelis" odnosi się jednak również do konkretu, określa wtedy człowieka 1 znaczy: "wierny" / konotacja religijna/; "wierzacy", "nawrócony", "taki, który przyją chrzest"/konotacja religijna/; "godny zaufania", "rzetelny" /konotacja raczej świecka, etyczna, uogólniająca/. Wyraz "fidelis" w uzyciu rzeczownikowym znaczy: "chrześcijanin", "wierny wyznawca Chrystuśa".

Całość pracy zamyka "Zakończenie", które w rekapitulacji nawiązuje do wyników badań prowadzonych w latach 60-tych w Sekcji Filologii Klasycznej KUL, dotyczących znaczenia wyrazów "fides" i "fidelis" u św. Cypriana, św. Hilarego i Laktancjusza.

Ks. Henryk Wójtowicz - Lublin

\section{Elżbieta Krych, Symplicjusz. Listy. Wstęp - przekład - komentarz, Lublin 1986, maszynopis, s. XXIV + 60。}

Jest to praca magisterska napisana w Sekcji Filologii Klasycznej KUL pod kierunkiem ks. doc. dra hab. H. Wójtowicza, zawierająca wstęp, przekład wszystkich 21 listów papieża Symplicjusza /468-483/, komentarz, indeks osobowy $i$ bibliografie. Jest to pierwsze polsce tłumaczenie listów Symplicjusza/Simplicius/, powstałe z okazji 1500 rocznicy śmierci tego papieza. Główny trzon listów, to pisma skierowane do patriarchy konstantynopolitańskiego Akacjusza /471$489 /$ - jest ich 10 - oraz 4 listy adresowane do cesarza Wschodu Zenona /474-491/.

Listy te stanowią ciekawą dokumentację z czasów kształtowania się $i$ umacniania władzy papieskiej, przy jednoczesnym upadku władzy cesarskiej na Zachodzie. Symplicjusz zajmuje się w nich sprawa prawidłowej elekcji i konsekracji biskupów, a także troszczy się o przestrzeganie uchwał Soboru Chalcedońskiego /451/; z jednej strony usiłuje,osłabić wpływy wyznawców monofizytyzmu na Wschodzie, z drugiej zaś wzmocnić pozycję biskupów ortodoksyjnych. Jest to niewątpliwie interesująca pozycja dla badaczy prawa kanonicznego, historyków, Pilologów, a zwłaszcza dla zajgujących się przyczynami powstania pierwszej schizmy na Wschodzie, jaka była 